\title{
Low-cost Foods and Drugs Using Immobilized Enzymes on Biopolymers
}

\author{
Assoc. Prof. Dr. Magdy M. Elnashar \\ Laboratory of Advanced Materials \& Nanotechnology, \\ Polymers and Pigments Department, \\ Centre of Excellence for Advanced Sciences, \\ National Research Centre, \\ 12622 Dokki, Cairo, \\ Egypt
}

\section{Introduction}

The cost of food and drugs is dramatically increasing on a universal scale, as a result, the production of low-cost foods and drugs is of major national concern. This abstract aims to summarize some of the authors research work on low-cost biopolymers, as an alternative to the expensive carriers, such as Eupergit $C^{\circledR}$, for the immobilization of industrial enzymes to produce more economical foods and drugs. The novel carriers are 15-25 times cheaper compared to the commercial ones in the market (Agaroses and Eupergit $C^{\circledR}$ ). The present work has been internationally reported and appreciated by specialized scientific websites.

From a preliminary study of the world markets and needs, three enzymes, namely, $\beta$ galactosdiase, inulinase and penicillin acylase, have been chosen for immobilization. $\beta$ galactosdiase will solve $70 \%$ of the worldwide population suffering from lactose intolerance, as well as, protecting the environment by converting wastes, as whey, to lactose free syrup; inulinase produces fructose, which is 4 times sweeter than glucose and has, additionally, the advantage of being recommended to diabetics and people on a diet. Penicillin acylase produces 6-aminopenicillanic acid (6-APA), which is the precursor for the production of $\mathbf{1 9 \%}$ of the worldwide antibiotics, such as Ampicillin and Amoxicillin.

Immobilization of enzymes on natural biopolymers, such as grafted carrageenan, chitosan and alginate will, practically, enable the separation and reusability of the enzymes for tens of times, which will, consequently, reduce both the enzyme and the product costs. Accordingly, we are expecting the prices of foods and drugs to be significantly reduced. One of the major advantages of the immobilization of enzymes, that we have achieved, is the improvement of the enzymes' thermal, as well as, operational stabilities.

\section{Worldwide food and drug crisis}

According to an assessment made by US AID, between March 2007 and 2008, global food prices were increased by an average of 43 percent, according to the International Monetary Fund. (1) During this time period, wheat, soybean, corn, and rice prices increased by $146 \%$, $71 \%, 41 \%$, and $29 \%$, respectively, according to the U.S. Department of Agriculture. The rise 
in food prices contributed to a significant increase in food insecurity worldwide, particularly among poorer populations. Similarly, the prices of drugs are dramatically increasing. (2) One of the main solutions available is to reduce the price of certain foods and drugs, through the manipulation of immobilized enzymes. Accordingly, in this chapter, we will shed the light on:

a. nature of enzymes,

b. uses of enzymes in different fields,

c. immobilized enzymes and immobilization techniques,

d. carriers for enzyme immobilization (including gel disks and bead formation), and finally, we will re-present some of the distinguished results we achieved in the production of low-cost food and drugs using some industrially immobilized enzymes.

\subsection{Nature of enzymes}

Enzymes are biological catalysts used for biotransformations, consisting of a protein component (biopolymer) and, in many cases, cofactors or prosthetic groups. Almost, all enzymes are proteins, however, some recent works reported the presence of catalytic activity in RNA. A catalyst, by its turn, is a molecule, which speeds up the chemical reaction, at which equilibrium is achieved without altering its position, and undergoing no insignificant chemical change in itself.(3)

Enzymes have the advantage of catalysing reactions under mild conditions, such as aqueous solutions, moderate temperatures and pressures, while operating with high specificity. In biological processes, enzymes are preferred to conventional chemical catalysts, for the following reasons: $(3-7)$

1. Enzymes increase the rate of reaction about $10^{5}-10^{14}$ over that of an uncatalysed reaction, e.g. a catalase increases the rate of decomposition of $\mathrm{H}_{2} \mathrm{O}_{2}$ into water and oxygen, as much as $10^{11}$ fold greater than an uncatalysed reaction and $10^{7}$ faster than the manipulation of a platinum based chemical catalyst.(8) Another example is carbonic anhydrase, which catalyses the hydration of up to 600,000 molecules of $\mathrm{CO}_{2}$ per second of carbonic acid.(4)

2. Enzymes reduce the activation energy barrier (energy difference between ground state and transition state), Figure 1.

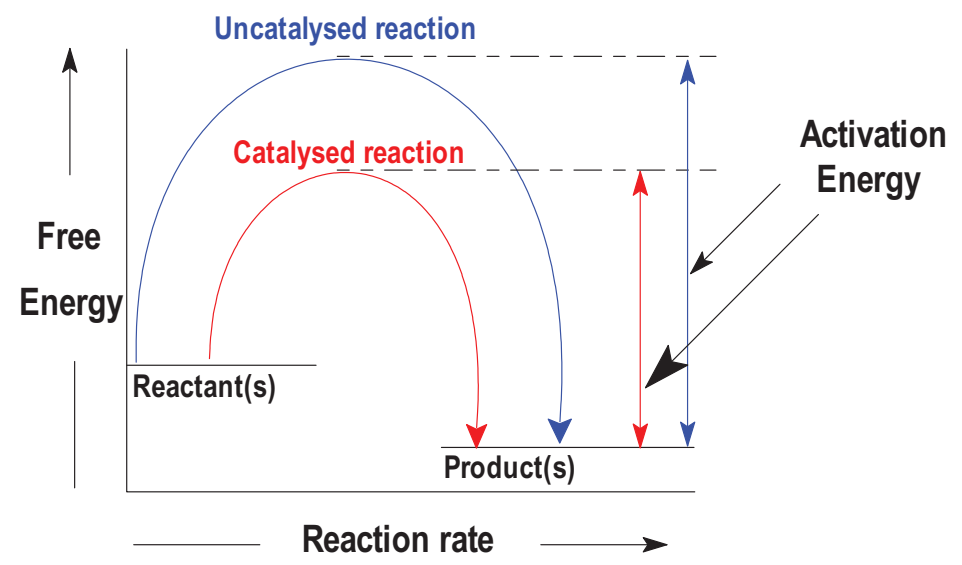

Fig. 1. Effect of enzyme catalysis on the activation energy of a system. The blue and red arrows indicate the uncatalysed and catalysed reactions respectively. 
3. Enzymic catalysis can take place at ambient temperatures, neutral $\mathrm{pH}$ and at atmospheric pressure, whilst efficient chemical catalysis generally requires an increase in one or more of these variables.

4. Enzyme catalysed reactions are specific and rarely give side products as a consequence of their reactions, while chemical catalysis are limited in specificity and may lead to a number of side products.

\subsection{Uses of enzymes in different fields}

The use of purified enzymes has been increasing in many fields, e.g. in the detergent, starch, brewing, and baking industries. Enzymes are also used in pharmaceutical, chemical and clinical applications. Biochemical methods are used in clinical diagnosis, e.g. for the measurement of protein, urea, $\mathrm{pH}$ and cholesterol.(4, 9) Common uses of enzymes in different fields (analytical, medical and industrial) are indicated in Table 1.

\subsection{Immobilized enzymes}

The worldwide figure of enzymes used in industries (except in medicines) is about $€ 1.5$ billion. In food and drug industries, enzymes are not preferred to be used in a free liquid state, since they can not be easily separated from the product, consequently, they are lost after the first use and some enzymes are very expensive (Fig. 2a). The immobilization technique would enable the reusability of enzymes (Fig. 2b) for tens of times, thus reducing the enzyme and product costs significantly.

\section{Free}

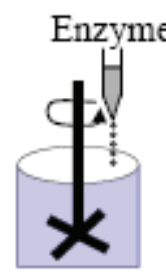

(a)
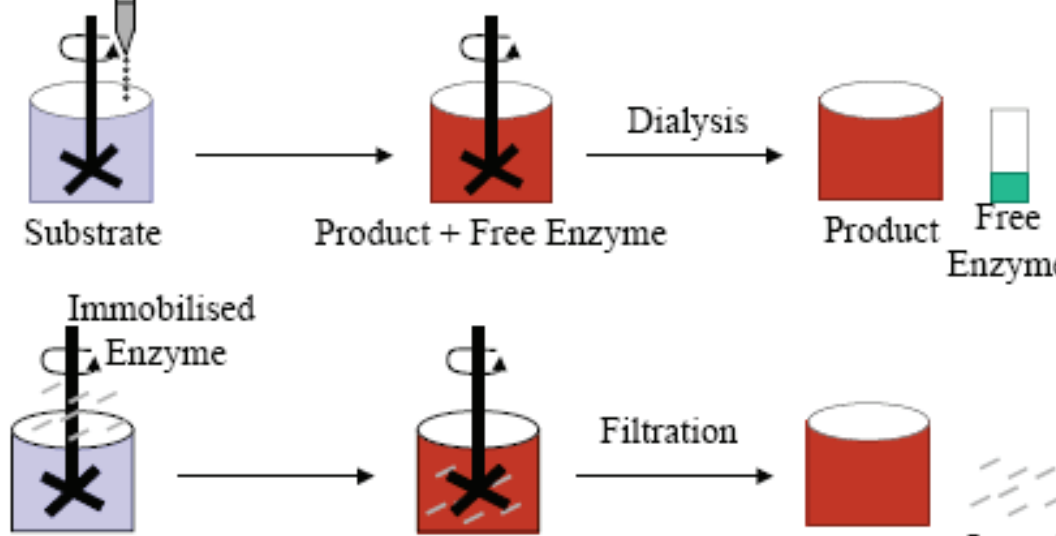

Substrate

(b)

Product + Free Enzyme

ilised

Enzyme
Product + Immobilised Enzyme
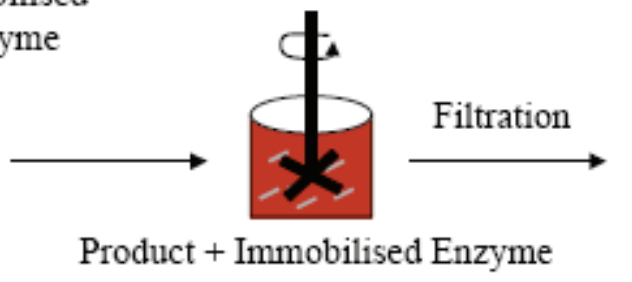

Product

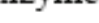

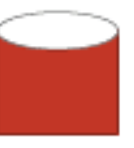

Product

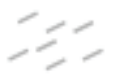

Immob. Enzyme

Fig. 2. a\&b Schematic diagram of free and immobilized enzyme reactions. (a), Reaction of free enzyme with substrate and formation of product, which has to be separated via dialysis; (b), Reaction of immobilized enzyme with substrate and formation of product, which can be separated via filtration. 


\begin{tabular}{|c|c|c|}
\hline Field & Enzymes & Uses \\
\hline \multirow[t]{6}{*}{ Analytical } & Glucose oxidase & $\begin{array}{l}\text { In glucose biosensors (biological molecule is } \\
\text { attached to a transducer). }\end{array}$ \\
\hline & $\begin{array}{l}\text { Glucose } \\
\text { dehydrogenase }\end{array}$ & $\begin{array}{l}\text { One enzyme system: detects the presence of } \\
\text { glucose in urine and blood. }\end{array}$ \\
\hline & $\begin{array}{l}\text { Glucose oxidase / } \\
\text { peroxidase }\end{array}$ & $\begin{array}{l}\text { Two enzyme system: detecting the presence of } \\
\text { glucose in urine and blood. }\end{array}$ \\
\hline & Urease & $\begin{array}{l}\text { Measures the concentration of urea in urine } \\
\text { samples. }\end{array}$ \\
\hline & Trypsin & $\begin{array}{l}\text { For protein sequence studies. In tissue and cell } \\
\text { dissociation. }\end{array}$ \\
\hline & $\begin{array}{l}\text { Lactate } \\
\text { dehydrogenase }\end{array}$ & $\begin{array}{l}\text { To measure reactions in which adenosine di- and } \\
\text { tri- phosphate, pyruvate are products. }\end{array}$ \\
\hline \multirow[t]{8}{*}{ Industrial } & Penicillinase & $\begin{array}{l}\text { In production of semi-synthetic antibiotics such as } \\
\text { penicillin, amoxycillin, ampicillin. }\end{array}$ \\
\hline & Inulinase & Production of fructose and high fructose syrup \\
\hline & Lipase & Hydrolyses lipids in food industries. \\
\hline & $\beta$-galactosidase & Hydrolyses lactose to glucose and galactose. \\
\hline & Chymosin & In the production of cheese. \\
\hline & $\begin{array}{l}\text { Pectinase and } \\
\text { cellulase }\end{array}$ & $\begin{array}{l}\text { In fruit juice industries (to hydrolyse pectin and } \\
\text { cellulose). }\end{array}$ \\
\hline & Xylanase / phytase & In animal feeds, to improve their nutritional value. \\
\hline & Detergent enzymes & $\begin{array}{l}70-80 \% \text { of purified enzymes are used in } \\
\text { detergent industries. }\end{array}$ \\
\hline \multirow[t]{4}{*}{ Medical } & Catalase & $\begin{array}{l}\text { Eliminates hydrogen peroxide (a potentially } \\
\text { harmful substance) from the body. }\end{array}$ \\
\hline & L-asparaginase & As an anticancer agent. \\
\hline & Proteases & In treating thrombosis. \\
\hline & Lactoperoxidase & $\begin{array}{l}\text { Prevents dental caries by the production of } \\
\text { hypothiocyanate ions. }\end{array}$ \\
\hline
\end{tabular}

Table 1. Use of enzymes in different fields. 
Adsorption

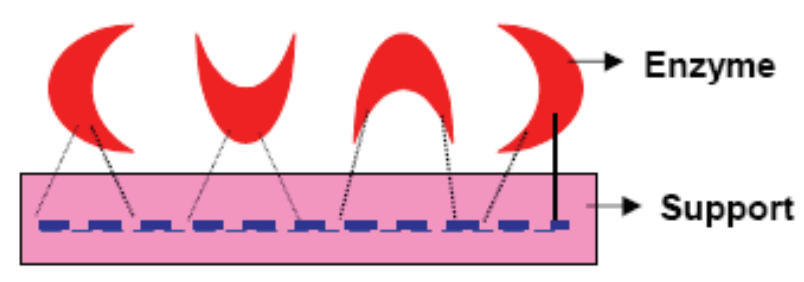

Covalent

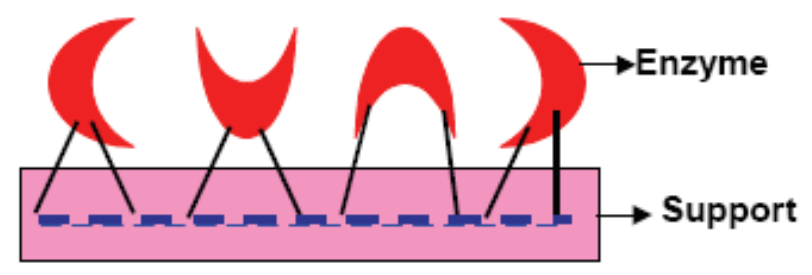

Entrapment

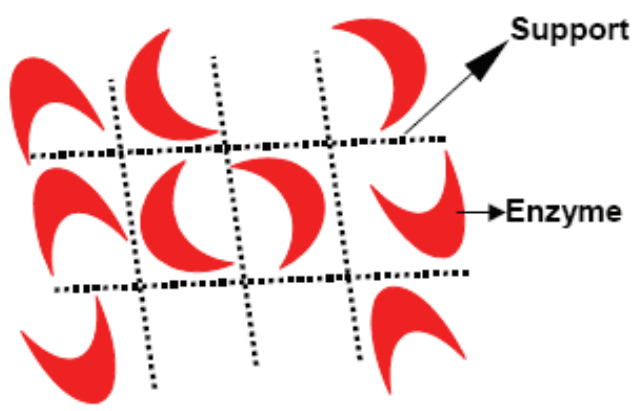

Encapsultation

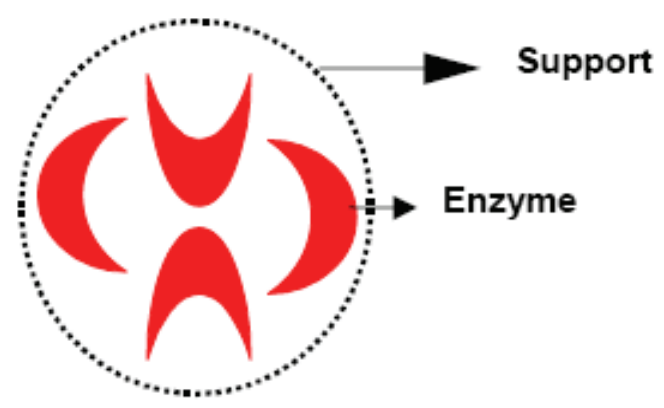

Crosslinking

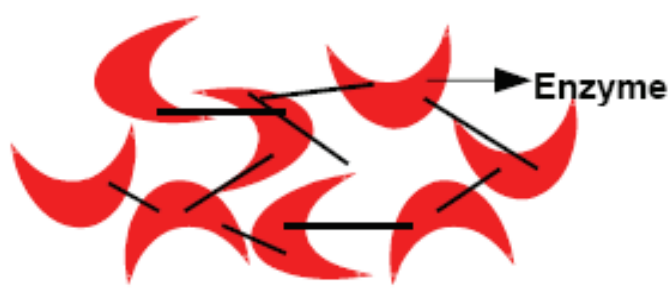

Fig. 3. Immobilization of enzymes using different techniques. 
Several techniques have been used for enzyme immobilization (Fig. 3), including entrapment(10), cross-linking(11, 12), adsorption(13), or (an) alternatively a combination of these methodologies.(14) Industrial surfaces such as glass beads(15), nylon-6(16), chitosan(17), Eupergit $\mathrm{C}^{\circledR}$ (epoxy-activated acrylic beads) and Agaroses ${ }^{\circledR(18)}$ have been variably used for this purpose. However, efficient commercial carriers suitable for the immobilization of enzymes are fairly expensive(19). For examples, available carriers such as Eupergit $C^{\circledR}$ or Agarose ${ }^{\circledR}$ are sold for $€ 6,000$ and $€ 3,250 / \mathrm{kg}$, respectively. (5) Accordingly, the need for a cheaper carrier is still an industrial dream, to compensate the high costs of their entire inputs.

\subsection{Carriers for enzyme immobilization}

To prepare a new carrier for enzyme immobilization, it is naturally an advantage if substances that are already permitted for use in the pharmaceutical or food industries can be utilized. Hydrogels such as alginates and carrageenans are biopolymers belonging to this commercially available category, have diverse features, and are available at a reasonable cost.(20)

\subsubsection{Alginates}

Alginates are produced by brown seaweeds (Phaeophyceae, mainly Laminaria). Alginate consists of monomeric residues of D-mannuronic acid and L-gluronic acid (Fig. 4). The gels are formed by ionic network formation in the presence of cations such as calcium ions or other multivalent counter-ions. This method qualifies as safe, mild, fast and cheap.

However, high concentrations of alginate are difficult to work with. Chelating agents such as phosphates and citrates are best avoided as they disrupt the gel structure by binding calcium ions.(21) Microspheres of alginate were produced using an encapsulation technique to immobilize glucoserebrosidase, as an enzyme delivery matrix for treatment of Gaucher's disease.(22) In terms of immobilization of enzymes, the entrapment method is widely used; for example, Tanaka et al. (1984) immobilized glucoamylase using Ca-alginate gel, coated with partially quaternized polyethyleneimine 3, whereas, keratinase was entrapped into Caalginate gel and $47 \%$ of the total enzyme activity was retained after immobilization.(23)

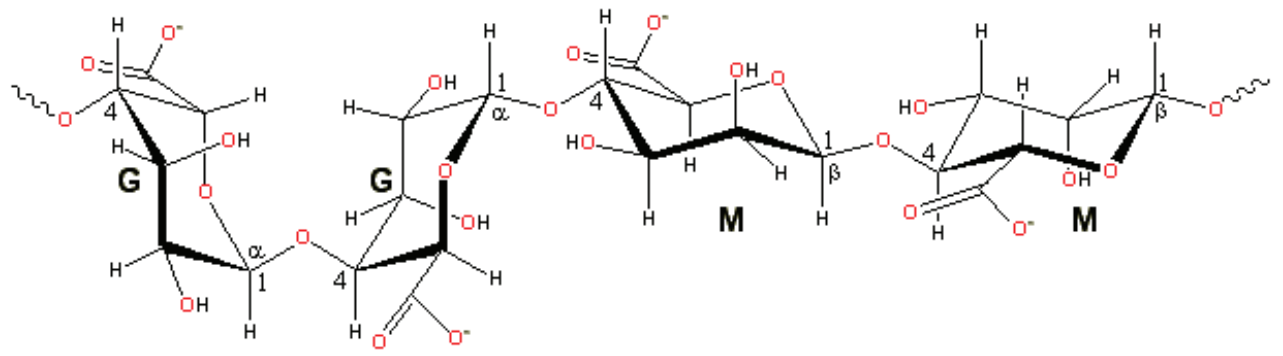

Fig. 4. Structure of Alginates. Alginates are linear unbranched polymers containing $\beta$-(14)linked D-mannuronic acid (M) and a-(14)-linked L-guluronic acid (G) residues.

\subsubsection{Carrageenans}

Carrageenans are produced from red seaweeds (Rhodophycae). They are water-soluble, sulphated galactans that are isolated from red seaweed and contain hydroxyl and sulphate groups. There are three forms of carrageenans: k-carrageenan, 1 -carrageenan, and $\lambda$ carrageenan and they differ in their ratios of sulphate to hydroxyl groups (Fig. 5).(24) 
Carrageenan has been used for the immobilization of enzymes and cells using entrapment techniques. It is inexpensive, but suffers from weak mechanical and thermal stability. Some work has been performed to improve its mechanical and thermal stability and it was found that the gels mechanical strength increased with the increased addition of 3,6-anhydro-Dgalactose 2-sulphate in the polymer, (25) or after addition of gums. (26) $\mathrm{K}^{+}, \mathrm{Al}_{3}{ }^{+}$were also found to improve the gels characteristics. (27)

In the field of immobilization of enzymes, k-carrageenan is one of the main supports used for cell and enzyme immobilization via entrapment, for example, k-carrageenan was used to immobilize $\alpha$-chymotrypsin using an encapsulation method.(28) However, one of the main disadvantages of these biopolymers is that they are usually used for immobilization of enzymes using noncovalent bonds (mainly entrapment/encapsulation) due to the lack of functionalities(29) as shown in Figure 4 \& 5. Unfortunately, the entrapment of enzymes in hydrogels is often characterized by some diffusion of the biocatalyst from the support, particularly for enzymes with molecular weight less than $300 \mathrm{kDa}$.(30) Recently, a few authors were successful at covalently immobilizing enzymes using hydrogels, and we were fortunate to be among them.(31-35) Some specialized websites highly appreciated our work and distinguishably, published them. (36-38)

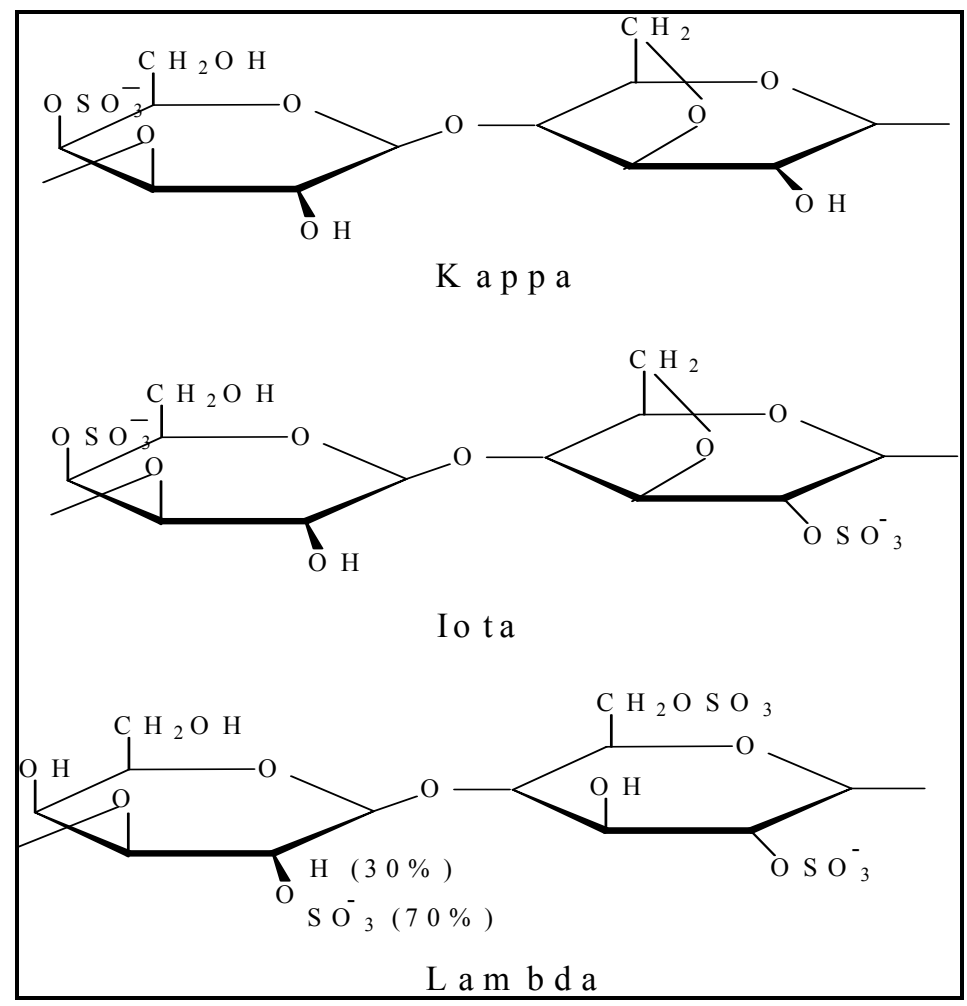

Fig. 5. Structures of repeating units in major carrageenan. Kappa carrageenan (k-) has one sulphate group, iota carrageenan (1-) has two sulphate groups and lambda carrageenan $(\lambda)$ has three sulphate groups. 
In our laboratories, we succeeded to incorporate a new functionality to alginate and carrageenan gels (aldehyde groups) for covalent immobilization of enzymes. The alginate gels were prepared in uniform beads shape using the "Encapsulator" (Fig. 6), (34, 35) whereas k-carrageenan gels were prepared in uniform disks using our invented equipment "parallel plates" (Fig. 7). (39)

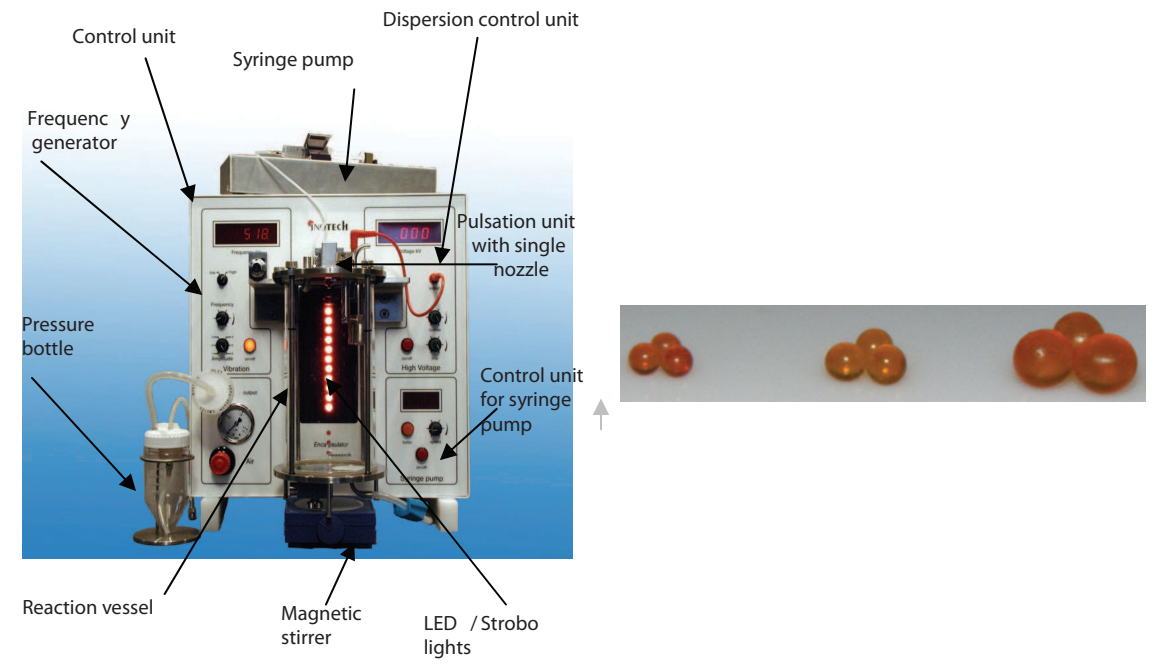

Fig. 6. Encapsulator for making uniform gel beads.
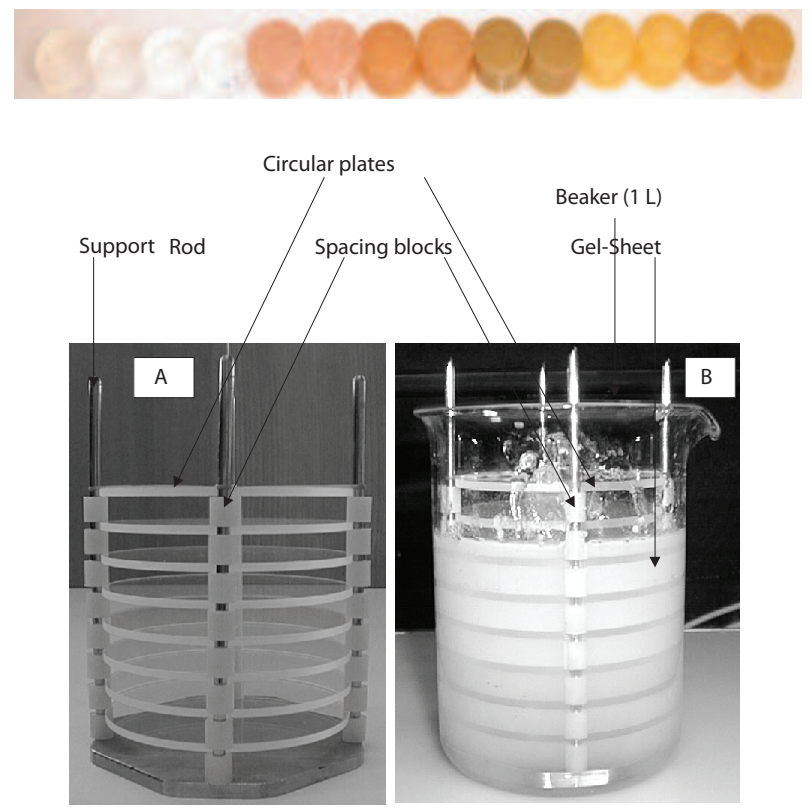

Fig. 7. Parallel plates equipment for making uniform k-carrageenan gel disks.(39) 
To overcome the problem of the gels' low thermal stability, both gels were treated with polyamines to form a polyelectrolyte complex. According to Chao, et al., 1986,(40) the thermal stability of k-carrageenan gels could be improved by adding amine compounds and, especially polyamine compounds. For this reason, natural polyamines such as chitosan (Figure 8) and synthetic ones such as polyethylenimines (Figure 9) were used to improve the carrageenan and alginate gels' thermal stabilities.(30-35)

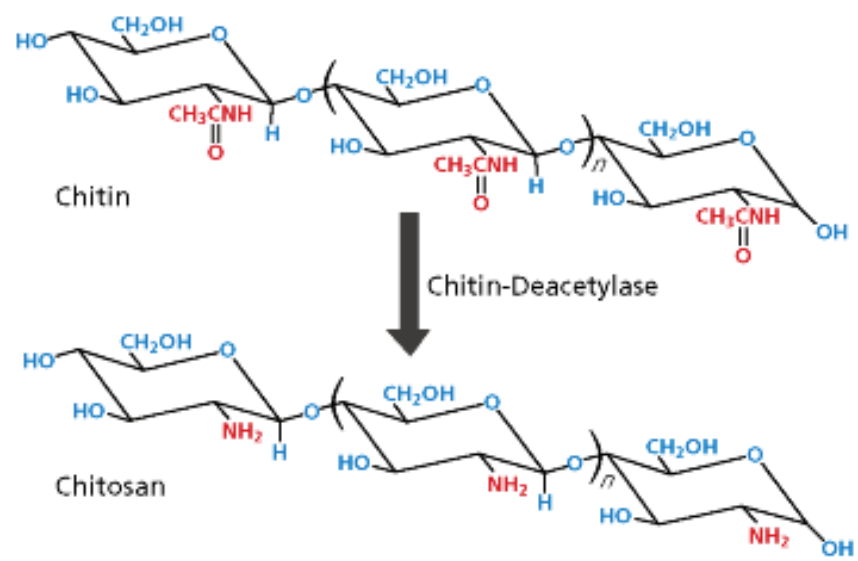

Fig. 8. Structure of chitin and chitosan.

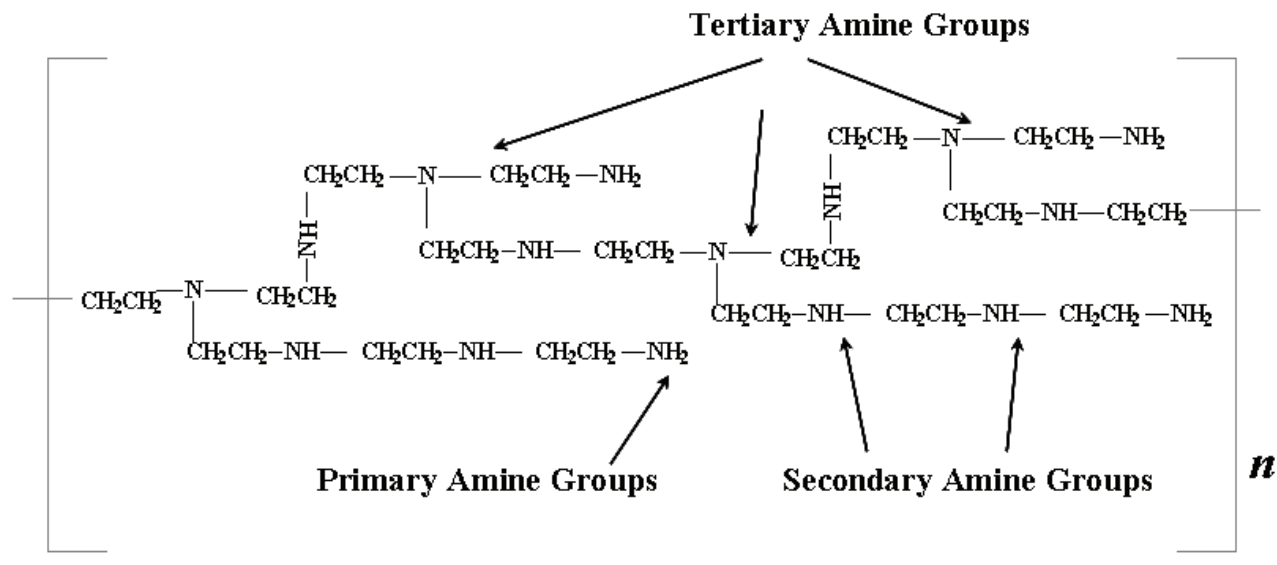

Molecular weight of this section $=716$

Fig. 9. Polyethyleneimine (PEI): A branched chain cationic polymer. Ratio of primary: secondary: tertiary amine groups is 1:2:1

\subsubsection{Chitin and Chitosan}

Chitin and chitosan are polysaccharides containing amino groups. They are attractive and widely studied as they are inexpensive. Chitin is an abundant by-product of the fishing and the fermentation industries. It is composed of $(1,4)$-linked 2 -acetamido-2-deoxy- $\beta$-D- 
glucopyranosyl residues. Chitosan is composed of (1,4)-linked 2-amino-2-deoxy-D-glucose and is obtained from chitin by deacetylation, at high $\mathrm{pH}$. It is more soluble than chitin and can be gelled by either crosslinking agents such as glutaraldehyde, or by multivalent anionic counter-ions such as $\left[\mathrm{Fe}(\mathrm{CN})_{6}\right]^{4-}$ or polyphosphates. Chitin and chitosan can be prepared in the form of beads and capsules and enzymes can be immobilized using ionotropic gelation methods.(41)

\subsubsection{Polyethylenimine}

It is a synthetic cationic polymer that contains primary, secondary and tertiary amine groups in its skeleton. Polyethylenimine (PEI) is available in different molecular weights and in linear and branched forms. PEI has been widely used to crosslink the gel surfaces after entrapping enzymes to avoid their leakages, for example, Tanaka et al (1984) (42), immobilized glucoamylase using Ca-alginate gel coated with partially quaternized polyethyleneimine.

The novelty of this work resides in the realized production of thermally stable biopolymers of carrageenan and alginates gels treated with polycations. Evidently, this was not only to improve the gels' thermal stabilities, but also to immobilize the enzymes into the modified gels via covalent bonding. Glutaraldehyde was used as both a mediator and as a crosslinker. Three industrial enzymes have been chosen for immobilization due to their industrial importance in the production of low-cost foods and drugs, as follows:

a. penicillin $\mathrm{G}$ acylase (PGA),

b. inulinase, and

c. $\beta$-galactosidase

\section{a) Penicillin acylase}

Penicillins are a group of small compounds with important antibacterial properties. They are the most widely used $\beta$-lactam antibiotics, with a share of about $19 \%$ of the estimated world-wide antibiotic market.(43) In particular, they are effective against the microorganisms responsible for several diseases such as tetanus, diphtheria, syphilis, gonorrhoea and skin boils. Penicillin acylase catalyses the hydrolysis of penicillin G (PG) to phenyl acetic acid (PAA) and 6-aminopenicillanic acid (6-APP) (Figure 10), ${ }^{(44)}$ which is the building block for production of semi-synthetic $\beta$-lactam antibiotics, ${ }^{(45)}$ as shown in Table 2.

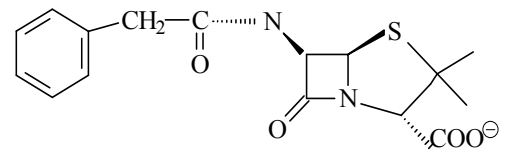

Penicillin G Acylase

Penicillin G

(PG)<smiles>CC1(C)SC2C([NH])C(=O)N2C1C(=O)[O-]</smiles>

6-Aminopenicillinic Acid (6-APA)
Phenyl acetic acid (PAA)

Fig. 10. Hydrolysis of penicillin $G$ by penicillin $G$ acylase. 
Modified semisynthetic penicillins have three distinct advantages over native PG. Firstly, some of them, such as ampicillin and cloxacillin, are acid stable, and are therefore suitable for oral intake. Secondly, methicillin and cloxacillin are resistant to beta-lactamase activity. Lastly, synthetic penicillins have a significant increased range of susceptible bacteria including many bacteria that are not usually inhibited by PG.

\begin{tabular}{|l|l|}
\hline & \multicolumn{2}{|c|}{ Penicillin core structure } \\
\hline & Penicillin Variant \\
\hline & \\
\hline
\end{tabular}

Table 2. Structural comparison between some semi-synthetic penicillins and naturally produced penicillin G.

\section{b) Inulinases}

Inulinases are one of the most important enzymes used in industries. Inulinases are $\beta$ fructan fructanohydrolases (EC 3.2.1.7), which hydrolyze inulin, to produce fructose and fructo-oligosaccharides, both of which are important ingredients in food and pharmaceutical industries. Inulin is a polysaccharide of $\beta$-(2,1)-linked fructose residues 
attached to a terminal glucose molecule and is accumulated in the underground organs of chicory, dahlia, and Jerusalem artichoke. Fructose can be produced from starch by enzymatic methods involving R-amylase, amyloglucosidase, and glucose isomerase, resulting in the production of a mixture consisting of oligosaccharides (8\%), fructose $(45 \%)$, and glucose (50\%). (46) Separation of fructose from this high fructose syrup is costly and thus makes this method uneconomical. An alternative procedure involves the use of inulinase, which yields $95 \%$ of pure fructose after one step of the enzymatic hydrolysis of inulin. Industrial inulin hydrolysis is carried out at $60^{\circ} \mathrm{C}$ to prevent microbial contamination and also because it permits the use of higher inulin substrate concentration due to increased solubility. Thus, a thermostable inulinolytic enzyme would be expected to play an important role in food and chemical industries, in which fructose syrup is widely applied. (47)

\section{c) $\beta$-galactosidase}

$\beta$-galactosidase is widely used in milk industries for hydrolysis of lactose to glucose and galactose. Lactose is the main carbohydrate contained in milk at a concentration between $5 \%$ and $10 \%(\mathrm{w} / \mathrm{v})$ depending on the source of milk.(48) Lactose can also be found in whey permeate at higher concentrations. The consumption of foods with a high content of lactose presents a medical problem for approximately $70 \%$ of the world population, especially in the developing countries, as the naturally present enzyme in the human intestine, loses its activity during lifetime. (49) Undigested lactose in chyme retains fluid, bacterial fermentation of lactose results in production of gases, diarrhoea, and bloating, abdominal cramps after consumption of milk and other dairy products.

Unfortunately, there is no cure to lactose intolerance. This fact, together with the relatively low solubility and sweetness of lactose, has led to an increasing interest in the development of industrial processes to hydrolyze the lactose contained in dairy products (milk and whey) with both the free and immobilized conditions. (50) Studies have shown that glucose and galactose products hydrolyzed from lactose, are four times sweeter than lactose, more soluble, more digestible,(51) and can be consumed by 'lactose intolerant' people. (48-52) Hydrolysis of lactose present in whey permeate will produce lactose-free syrup, solving an aquatic pollution problem, since whey is commonly thrown in water sources.

\section{Some distinguished results}

Some of the notable data, we achieved by immobilizing the enzymes are the improvement of the enzymes' optimum temperature, and operational stabilities as a result of immobilization, some examples are herein presented:

\subsection{Enzyme's optimum temperature}

As shown in Figures 11-13, the optimum temperature of the immobilized enzymes is always higher than that of the free enzymes. For example, the optimum temperature for:

- free PGA was $60^{\circ} \mathrm{C}$, whereas for immobilized PGA it was at $70{ }^{\circ} \mathrm{C}$.

- free inulinase was $50{ }^{\circ} \mathrm{C}$, whereas for immobilized inulinase it was at $60{ }^{\circ} \mathrm{C}$.

- $\quad$ free $\beta$-galactosidase was $45^{\circ} \mathrm{C}$, whereas for immobilized $\beta$-galactosidase it was at $55^{\circ} \mathrm{C}$.

This shift of the enzyme's optimum temperature after immobilization could be attributed to the formation of a molecular cage around the protein molecule (enzyme), which the concomitant protection of the enzyme's molecules from the surrounding bulk temperature.(53) 


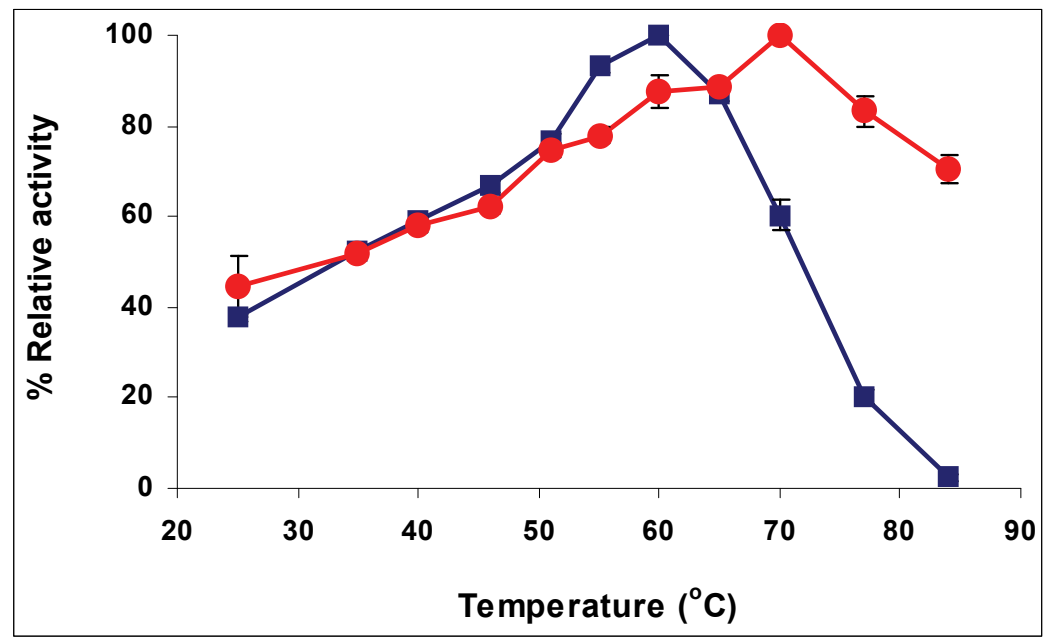

Fig. 11. Optimisation of assay temperature for free and immobilized PGA. Free PGA and immobilized PGA. (31)

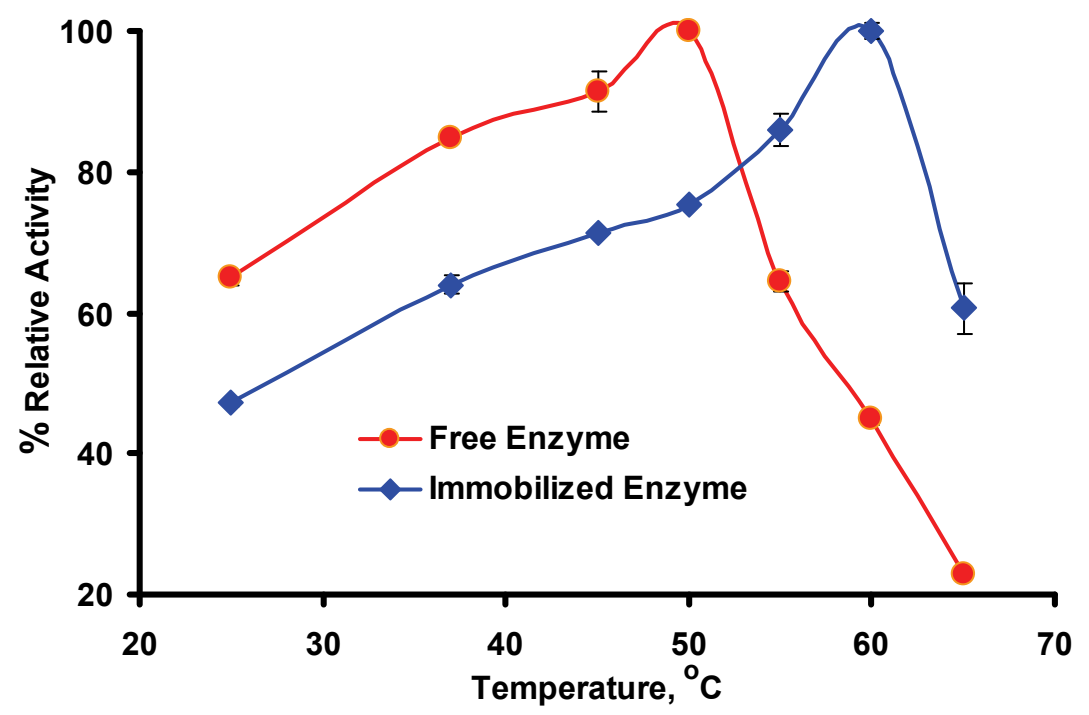

Fig. 12. Optimum temperature profile of free and immobilized inulinase.(34) 


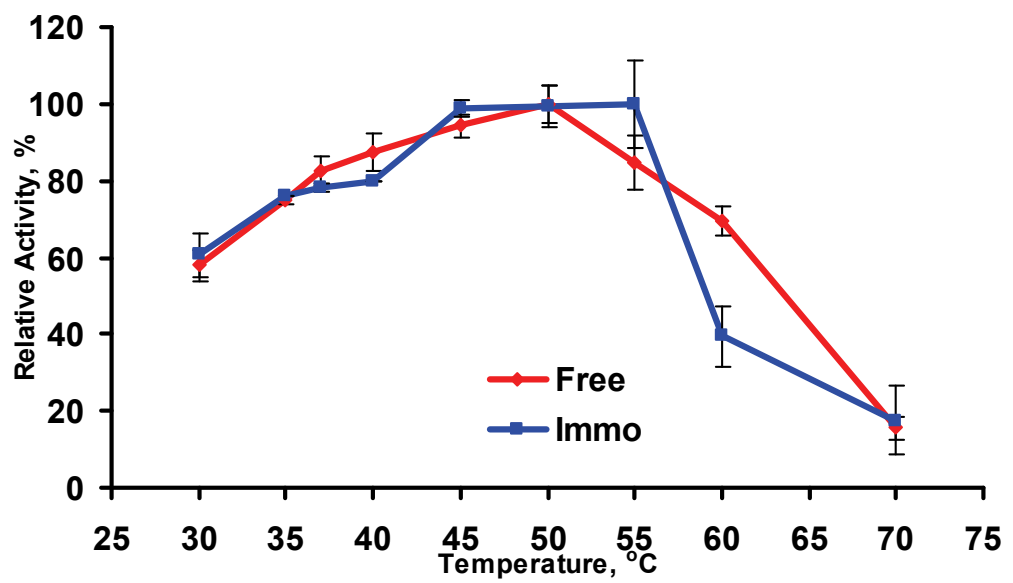

Fig. 13. Temperature-activity profile of free and immobilized $\beta$-galactosidase.(32,33)

\subsection{Enzymes' operational stability}

The major advantage of enzyme immobilization is the easy separation and reusability of the starting enzyme. The data shown in Figure 14-16 indicates that there was almost no decrease in the enzyme activity for the immobilized PGA and inulinase for 20 reuses, and for $\beta$-galactosidase for 9 reuses. (54) However, for $\beta$-galactosidase, after the ninth use, the relative enzyme activity started to gradually decrease, to attain $97 \%$. The loss in activity could be attributed to the inactivation of enzyme due to continuous use.(55)

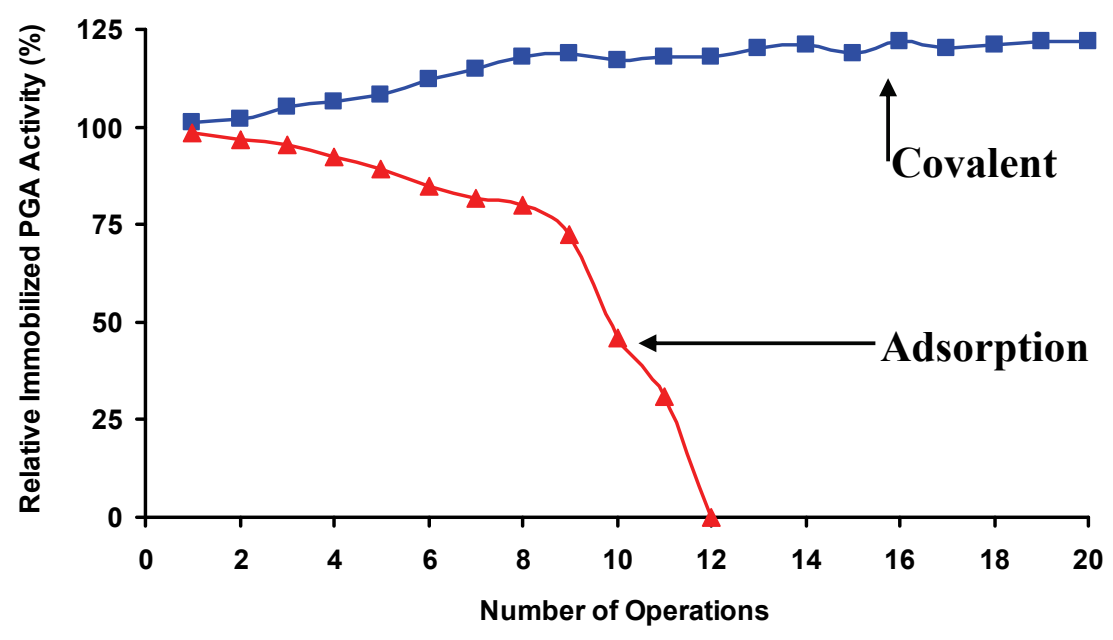

Fig. 14. Operational stability of immobilized PGA. Using modified gel (Carr/PEI/GA) and a control gel (Carr/ $\mathrm{KCl})$ for immobilization of PGA.(31) 


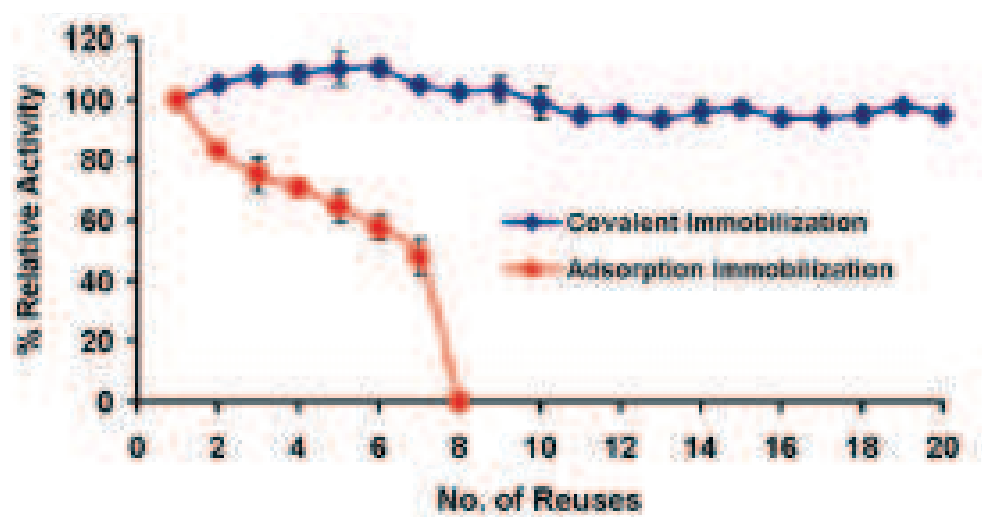

Fig. 15. Operational stability of immobilized inulinase on control gel $\left(\mathrm{Alg} / \mathrm{Ca}^{2+}\right)$ and grafted alginate (Alg/PEI/GA).(34, 35)

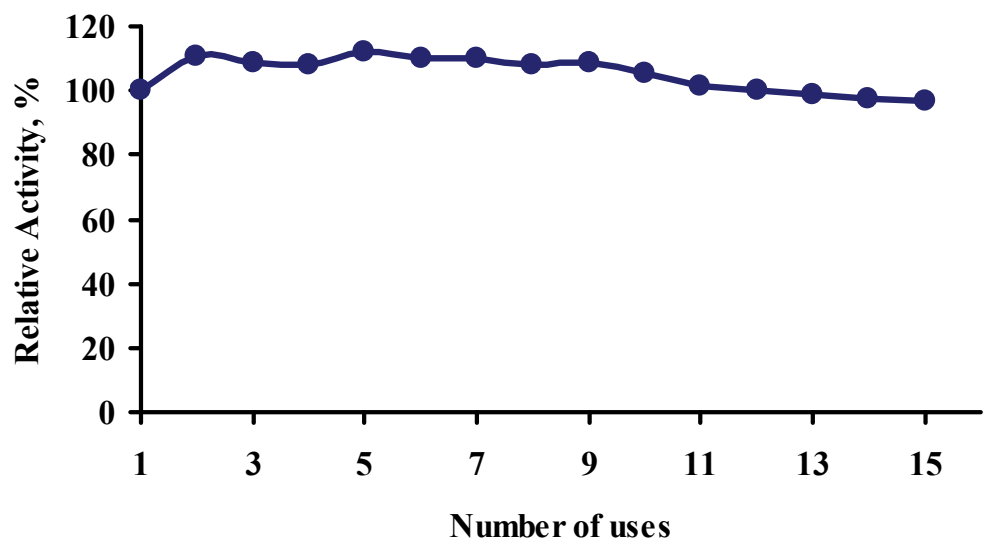

Fig. 16. Operational stability of immobilized $\beta$-galactosidase onto the modified gel (carrageenan/chitosan/glutaraldehyde). $(32,33)$

\section{Conclusion}

The modification of carrageenan and alginate biopolymers with chitosan/PEI imparts three extra benefits to these biopolymers. The first is the creation of a new amino groups functionality; the second, is the amelioration of the gel's thermal stability by forming a polyelectrolyte complex (PEC), while the third is the use of the free amino groups to covalently immobilize enzymes, via glutaraldehyde, as a mediator and a crosslinker.

Three industrial enzymes were immobilized using the modified gels to produce low-cost foods and drugs.

1. Penicillin G acylase (PGA) produces 6-APA, which is the precursor for production of $19 \%$ of the worldwide antibiotics, such as Ampicillin and Amoxicillin.

2. Inulinase produces fructose, which is 4 times sweeter than glucose (used in high fructose syrups) and has the advantage of being recommended to people on a diet and diabetics; 
3. $\beta$-galactosdiase produces glucose from lactose, which will solve $70 \%$ of the worldwide population suffering from lactose intolerance in milk and dairy products as well as protecting the environment by converting wastes, as whey, to lactose free syrup.

The novel carriers increased the enzymes' optimum temperature due to formation of a cage around the enzymes, protecting the enzyme from the bulk solution's temperature. The most important advantage of immobilization is the operational stability, where the enzymes have been used for up to 15 and 20 cycles with almost no loss of activity. In accordance, the reusability of the immobilized enzyme for tens of times tremendously reduces the enzyme, as well as the enzymatic products cost, e.g. antibiotics and fructose.

In brief, the simplicity and effectiveness of the newly developed methods for covalent immobilization of enzymes, in addition to the realized promising results for the operational stabilities are encouraging to be applicable on the industrial levels, for the prosperity of human beings.

\section{Acknowledgement}

The author would like to thank the Centre of Excellence, NRC, Egypt, for Advanced Sciences, the RDI and the STDF/IMC for supporting this work, and highly appreciates the efforts of Mrs Joanne Yachou and Professor Mohamed Abo-Ghalia for their contribution towards editing.

\section{References}

[1] http://www.usaid.gov/our_work/humanitarian_assistance/foodcrisis/

[2] http://healthinsurance.about.com/b/2006/06/23/drug-prices-increasedramatically.htm

[3] Loewy, A. G, Siekevitz, P., Menninger, J. R. \& Gallant, J. A. N. (1991). “Cell structure and function: an integrated approach" (3rd edition). Saunders college publishing, Philadelphia. $p p$ 133-258.

[4] Bickerstaff, G. F. (1987). Enzymes in industry and medicine. Edward Arnold, London. pp 1-95.

[5] Elnashar, M. M. (2010). In Biopolymers: Bioapplications of chitosan. Novapublisher, Accepted and in press.

[6] Fisher, J. Arnold JPR. (1999). In chemistry for biologists. BIOSS Scientific Publishers Ltd. Oxford. $p p$ 64-95, 198-207.

[7] Voet, D. \& Voet, J. G. (1995). Biochemistry. New York: John Wiley \& Sons. pp 29-104 \& 331-370.

[8] Hartmeier, W. (1988). Immobilized biocatalysts. Spring-Verlag, New York. pp. 4-90.

[9] Boyer, R. F. (1993). In modern experimental biochemistry (2nd edition). The Benjamin / Cumming publishing company, Inc., pp. 29 - 58 \& 115 - 127.

[10] Betancor, L., Luckarift, R., Seo, H. \& Brand, O. (2008). Three-dimensional immobilization of $\beta$-galactosidase on a silicon surface. Biotechnol Bioeng, 99, 261.

[11] Wang, Y., Xu, J., Luo, G. \& Dai, Y. (2008). Immobilization of lipase by ultrafiltration and cross-linking onto the polysulfone membrane surface. Biores Technol, 99, 2299.

[12] Jozef, S. \& Sylwia W. (2006). Immobilization of thermostable $\beta$-glucosidase from Sulfolobus shibatae by cross-linking with transglutaminase. Enz Microb Technol, 39, 1417.

[13] Salah, S., Srimathi, S., Gulnara, S., Ikuo, S. \& Bengt, D. (2008). Hydroxyapatite as a novel reversible in situ adsorption matrix for enzyme thermistor-based FIA. Talanta, 77, 490. 
[14] D'Souza, S. F. (1999). Immobilized enzymes in bioprocess. Current Sci, 77, 69.

[15] Kahraman, V., Bayramoglu, G., Kayaman-Apohan, N. \& Atilla, G. (2007). a-Amylase immobilization on functionalized glass beads by covalent attachment. Food Chem, $104,1385$.

[16] Shweta, P., Shamsher, K., Ghanshyam, C. \& Reena, G. (2008). Glutaraldehyde activation of polymer Nylon- 6 for lipase immobilization: Enzyme characteristics and stability. Biores Technol, 99, 2566.

[17] Emese, B., Ágnes, N., Csaba, S., Tivadar, F. \& János, G. (2008). Preparation of chitosan particles suitable for enzyme immobilization. J Biochem Biophys Meth, 70, 1240.

[18] Peppler, H. J., \& Reed, G. (1987). Enzymes in food and feed processing. In H. J. Rehm, G. Reed (Eds.), Biotechnology, vol. 7a (pp. 578). Weinheim: VCH

[19] Bickerstaff, G. F. (1995). Impact of genetic technology on enzyme technology. Genet Eng Biotechnol, 15, 13.

[20] Hugerth, A., Caram-Lelham, N. \& Sundeliir, L. The effect of charge density and conformation on the polyelectrolyte complex formation between carrageenan and chitosan. Carbohydr Polym, 1997, 34, 149.

[21] Woodward, J. (1985). Immobilized enzymes: adsorption and covalent coupling in Immobilized Cells and Enzymes: A practical Approach. Woodward, J., ed., IRL, Oxford. $p p$ 3-17.

[22] Ribeiro, C. C., Barrias, C. C. \& Barbosa, M. A. (2004). Calcium phosphate-alginate microspheres as enzyme delivery matrices. Biomat, 25, 4363.

[23] Farag, A. \& Hassan, M. (2004). Purification, characterisation and immobilization of a keratinase from Aspergillus oryzae. Enz Microb Technol, 34, 85.

[24] Gerhard, A. \& Brian, R. (1997). Carrageenan biotechnology. Trends Sci Technol, 8, 389.

[25] Ainsworth, P. A. \& Blanshard, J. M. V. (1978). The interdependence of molecular structure and strength of carrageenan/carob gels. Part I. Lebensm.-Wiss. U.Technol., 11, 279.

[26] Audet, P., Paquin, C. \& Lacroix, C. (1990). Batch fermentations with a mixed culture of lactic acid bacteria immobilized separetly in k-carrageenan/locust bean gum gel beads. Appl. Microb. Biotechnol., 32, 662.

[27] Chamy, R., Nunez, M. J. \& Lema, J. M. (1990). Optimisation of the hardening treatment of S. cereviseae bioparticles. Biotechnol Bioeng, 30, 52.

[28] Belyaeva, E., Della Valle, D. \& Poncelet, D. (2004). Immobilization of $\alpha$-chymotrypsin in k-carrageenan beads prepared with the static mixer. Enz. Microb. Technol, 34, 108.

[29] Moon, S. \& Parulekar, S. J. (1991). Characterisation of k-carrageenan gels used for immobilization of Bacillus firmus. Biotechnol. Prog, 7, 516.

[30] Tanriseven, A, Dogan, S. (2002). A novel method for the immobilization of $\beta$ galactosidase. Process Biochem, 38, 27.

[31] Elnashar, M. M., Yassin A. M. \& Kahil, T. (2008). Novel thermally and mechanically stable hydrogel for enzyme immobilization of penicillin $G$ acylase via covalent technique. J Appl Polym Sci, 109, 4105.

[32] Elnashar, M. M. \& Yassin A. M. (2009a). Covalent immobilization of $\beta$-galactosidase on carrageenan coated chitosan. J Appl Polym Sci, 114, 17.

[33] Elnashar, M. M. \& Yassin A. M. (2009b). Lactose hydrolysis by $\beta$-galactosidase covalently immobilized to thermally stable biopolymers. Appl Biochem Biotechnol, $159,426$.

[34] Elnashar, M. M., Danial, E. N. \& Awad, G. E. (2009). Novel Carrier of Grafted Alginate for Covalent Immobilization of Inulinase. Indus Eng Chem Res, 48, 9781. 
[35] Danial, E. N., Elnashar, M. M. \& Awad, G. E. (2010). Immobilized Inulinase on Grafted Alginate Beads Prepared by the One-Step and the Two-Steps Methods. Indus Eng Chem Res, 49, 3120.

[36] http://goliath.ecnext.com/coms2/gi_0199-8982245/Studies-from-M-M-M.html

[37] http://www.verticalnews.com/premium_newsletters/Journal-of-technology/2008-0909/66896TE.html

[38] http://www.newsrx.com/newsletters/Medical-Devices-and-Surgical-technology-Week /2009-11-08/2811082009139QW.html

[39] Elnashar, M. M., Millner, P. A., Johnson, A.F. \& Gibson, T. D. (2005). Parallel plate equipment for preparation of uniform gel sheets. Biotechnol Lett, 27, 737.

[40] Chao, K. C., Haugen, M. M. \& Royer, G. P. (1986). Stabilization of k-Carrageenan Gel with Polymeric Amines: use of immobilized cells as biocatalysts at elevated temperatures. Biotechnol Bioeng, 28, 1289.

[41] Krajewska, B. (2004). Application of chitin- and chitosan-based materials for enzyme immobilizations: a review. Enz Microb Technol, 35, 126.

[42] Tanaka, H, Kurosawa, H, Kokufuta, E. \& Veliky, I. (1984). Preparation of immobilized glucoamylase using Ca-alginate gel coated with partially quaternized poly (ethyleneimine). Biotechnol Bioeng, 26, 1393.

[43] Parmar, A., Harish, K., Marwaha, S. S. \& Kennedy, J.F. (2000). Advances in enzymatic transformation of penicillins to 6-aminopenicillanic acid (6-APA). Biotechnol Adv, $18,289$.

[44] Balasingham, K., Warburton D., Dunnill P. \& Lilly M. D. (1972). Isolation and kinetics of penicillin amidase from Escherichia coli. Biochim Biophys Acta, 276, 250.

[45] Cole, M. (1969). Hydrolysis of penicillins and related compounds by the cell-bound penicillin acylase of Escherichia coli. Biochem J, 115, 733.

[46] Gill, P. Manhas, R. \& Singh, P. (2006). Hydrolysis of inulin by immobilized thermostable extracellular exoinulinase from Aspergillus fumigatus. J Food Eng, 76, 369.

[47] Vandamme, E. \& Derycke, D. (1983). Microbial Inulinases: Fermentation process, properties, and applications. Adv Appl Microbiol, 29, 139.

[48] Ordoñez, J. A., Cambero, M. A., Fernandez, L., Garcia, M. L., Garcia, G. \& Hoz, L. (1998). Tecnologia de los alimentos (II). Madrid, Spain: Editorial Sintesis.

[49] Richmond, M. Gray, J. \& Stine, C. (1981). Beta-galactosidase: Review of recent research related to technological application, nutritional concerns, and immobilization. J dairy Sci, 1759, 64.

[50] German, J. H. (1997). Applied enzymology of lactose hydrolysis. In Milk powders for the future, $p p .81$.

[51] Sungur, S., \& Akbulut, U. (1994). Immobilization of $\beta$-galactosidase onto gelatin by glutaraldehyde and chromium(III) acetate. J Chem Technol Biotechnol (Oxford, Oxfordshire) 59, 303.

[52] Nijipels, H. H. (1981). Lactases and their applications. In G. G. Birch, H. Blakebrough, \& K. J. Parker (Eds.), Enzyme and food processing (pp. 89). London: Applied Science Publishers.

[53] Tor, R., Dror, Y. \& Freeman, A. (1989). Enzyme stabilization by bilayer "encagement". Enz Microb Technol, 11, 306.

[54] Haider, T. \& Husain, Q. (2007). Preparation of lactose-free milk by using salt-fractionated almond (Amygdalus communis) $\beta$-galactosidase. J. Sci Food Agri, 87, 1278.

[55] Nakane, K., Ogihara, T., Ogata, N. \& Kurokawa, Y. (2001). Entrap-immobilization of invertase on composite gel fiber of cellulose acetate and zirconium alkoxide by solgel process. J Appl Polym Sci, 81, 2084. 


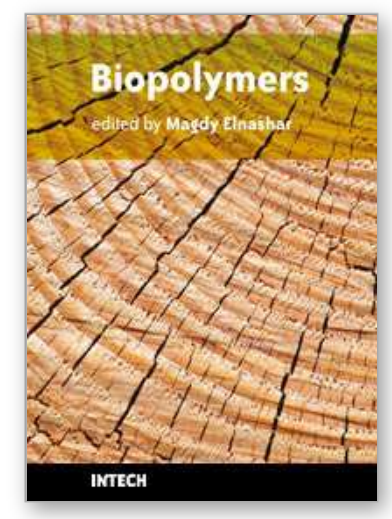

\author{
Biopolymers \\ Edited by Magdy Elnashar
}

ISBN 978-953-307-109-1

Hard cover, 612 pages

Publisher Sciyo

Published online 28, September, 2010

Published in print edition September, 2010

Biopolymers are polymers produced by living organisms. Cellulose, starch, chitin, proteins, peptides, DNA and RNA are all examples of biopolymers. This book comprehensively reviews and compiles information on biopolymers in 30 chapters. The book covers occurrence, synthesis, isolation and production, properties and applications, modification, and the relevant analysis methods to reveal the structures and properties of some biopolymers. This book will hopefully be of help to many scientists, physicians, pharmacists, engineers and other experts in a variety of disciplines, both academic and industrial. It may not only support research and development, but be suitable for teaching as well.

\title{
How to reference
}

In order to correctly reference this scholarly work, feel free to copy and paste the following:

Magdy Elnashar (2010). Low-Cost Foods and Drugs Using Immobilized Enzymes on Biopolymers, Biopolymers, Magdy Elnashar (Ed.), ISBN: 978-953-307-109-1, InTech, Available from: http://www.intechopen.com/books/biopolymers/low-cost-foods-and-drugs-using-immobilized-enzymes-onbiopolymers

\section{INTECH}

open science | open minds

\section{InTech Europe}

University Campus STeP Ri Slavka Krautzeka 83/A 51000 Rijeka, Croatia Phone: +385 (51) 770447

Fax: +385 (51) 686166 www.intechopen.com

\section{InTech China}

Unit 405, Office Block, Hotel Equatorial Shanghai No.65, Yan An Road (West), Shanghai, 200040, China 中国上海市延安西路65号上海国际贵都大饭店办公楼405单元 Phone: +86-21-62489820

Fax: +86-21-62489821 
(C) 2010 The Author(s). Licensee IntechOpen. This chapter is distributed under the terms of the Creative Commons Attribution-NonCommercialShareAlike-3.0 License, which permits use, distribution and reproduction for non-commercial purposes, provided the original is properly cited and derivative works building on this content are distributed under the same license. 